\title{
CONCORRÊNCIA: PANORAMA NO BRASIL E NO MUNDO
}

\author{
De Gesner Oliveira \\ São Paulo : Saraiva, 2001. 218 p.
}

Por Paulo Furquim de Azevedo, Professor Adjunto

do Departamento de Engenharia de Produção da

Universidade Federal de São Carlos (UFSCar).

E-mail: dpfa@power.ufscar.br

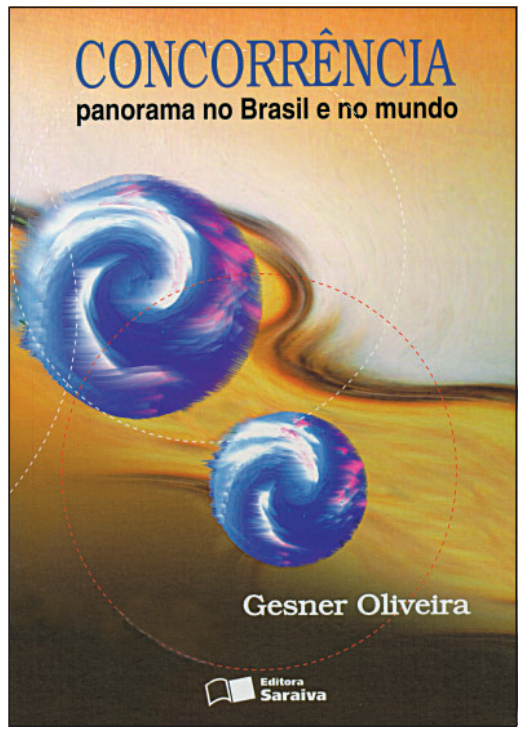

omo seria bom ouvir a história contada por seus próprios atores. Entretanto, infelizmente, nem sempre esses atores têm tempo ou oportunidade de dedicarem-se à narrativa, o que nos faz contentar-nos com as distantes, mesmo que equilibradas, análises de algum observador externo. O livro de Gesner Oliveira Concorrência: panorama no Brasil e no mundo é uma feliz exceção. Nele o autor trata, essencialmente, do sistema brasileiro de defesa da concorrência, que não só foi por ele presidido por oito anos, como também colocado na ordem do dia da política pública e das estratégias empresariais. Durante o período em que Gesner presidiu o Cade, o organismo cresceu em número de julgados, em produtividade, em recursos disponíveis e, em especial, em notoriedade.

O livro está estruturado em sete capítulos, cuja espinha dorsal é a discussão do modelo de desenho institucional da defesa da concorrência no Brasil. Em síntese, o livro reúne quatro temas centrais para a definição da configuração do sistema brasileiro de defesa da concorrência, que povoaram as discussões sobre o assunto na década de 90: a) as particularidades de uma economia emergente (Capítulo 1); b) a crescente integração comercial, no âmbito do Mercosul e da OMC (Capítulos 2 e 3); c) a definição de competências entre a agência de defesa da concorrência e as agências regulatórias setoriais, que ti- veram grande impulso após a privatização dos serviços de utilidade pública (Capítulos 4 e 5) e d) a relação entre investimento estrangeiro e defesa da concorrência (Capítulo 6). Finalmente, o Capítulo 7 reúne os argumentos desenvolvidos nos capítulos anteriores para uma finalidade de ação: uma crítica ao Anteprojeto de Criação de Agência de Defesa do Consumidor e da Concorrência e a proposta de um modelo alternativo.

A experiência do autor, aliada à sua sólida formação teórica, qualificam-no como um observador diferenciado do sistema brasileiro de defesa da concorrência. Entretanto, o que predomina no livro não é o autor-observador, mas o autor-ator, que organiza suas observações com o propósito da ação, de modificação de seu objeto de análise.

No Capítulo 4, o livro alcança sua maior sofisticação analítica, quando o desenho institucional do sistema brasileiro de defesa da concorrência incorpora sua relação com as agencias regulatórias setoriais. Nele são apresentadas cinco possíveis configurações institucionais, definidas pelo tipo de regulação e pelo agente responsável por conduzir a regulação. Como passo seguinte - e mais importante -, o autor desenvolve os critérios para a escolha da configuração institucional mais adequada, explorando diversos trade-offs, como o risco de captura, as economias de escala e escopo, o custo burocrático, entre 
outros. Da exploração desses trade-offs, é possível concluir que é desejável uma fusão entre SDE, SEAE e Cade, cujas rotinas administrativas são similares, e indesejável a formação de uma superagência, reunindo as diversas agências regulatórias setoriais, uma vez que o conhecimento específico necessário para cada uma delas reduziria os ganhos da fusão. Essa análise complementa os estudos coordenados pelo Ipea (ver Rezende e Paula, 1997) sobre regulação, que haviam antecipado alguns desses argumentos.

Embora esta seja uma das principais contribuições do livro, é no Capítulo 7 que o texto atinge o objetivo do autor-ator, sendo capaz de convencer o leitor das falhas do Anteprojeto de Criação de Agência de Defesa do Consumidor e da Concorrência. As críticas ao modelo em discussão são diversas e cuidadosamente explicitadas, incluindo vários aspectos ligados ao desenho institucional - como sua abrangência, organização, estrutura administrativa e de incentivos -, assim como aspectos diretamente relacionados ao controle de condutas e de atos de concentração.

Entre as críticas apontadas, chama à atenção a preocupação do autor com a história da defesa da concorrência no Brasil, que é considerada "um ativo raro entre países em desenvolvimento". Por esse motivo, sua proposta é fundamentalmente construída a partir da estrutura vigente, preservando a "Marca Cade".

Apesar de cerca de 30 anos de existência, a sigla Cade era, no início da década de 90, desconhecida do público em geral e mesmo de parte relevante dos atores econômicos. A notoriedade foi construída não somente pela presença de casos de grande repercussão pública, como os casos Kolynos-Colgate e Ambev, mas também por um esforço deliberado do Gesner e sua equipe na divulgação da cultura da concorrência.

Essa notoriedade, por sua vez, é um instrumento de fundamental importância para o exercício da função primária do Cade: disciplinar as práticas anticompetitivas, que venham a ferir a legislação de Defesa da Concorrência. Em suma, mais interessante que o número de julgados que implicam, em última instância, custos burocráticos e de transação nos casos sujeitos à análise - é a disciplina incutida nos negócios privados, que evitariam práticas cuja probabilidade de rejeição pelo Cade fosse elevada.

Nesse sentido, a notoriedade carrega duas importantes dimensões: a) sua magnitude (disseminação entre os atores econômicos) e b) a reputação associada à jurisprudência, que, por sua vez, se desdobra em dois componentes, a consistência das decisões e o seu perfil. Esta é uma escolha muito complexa por parte do Sistema Brasileiro de Defesa da Concorrência, pois deve lidar com o tradeoff do risco de aprovar uma operação que deveria, de fato, ser rejeitada e com o risco de bloquear uma operação que deveria ser aceita, o que representaria um custo ao processo de reestruturação industrial em curso.

Entre essas duas dimensões, a atuação mais expressiva do Cade, durante a década de 90, foi a disseminação da "cultura da concorrência", o que implica a inclusão da restrição institucional ao universo das estratégias empresariais. Além disso, houve aumento da consistência das decisões, decorrente de uma crescente sofisticação dos argumentos presentes nos votos e pareceres e, principalmente, da elaboração de um referencial mínimo de análise das transações.

Finalmente, é importante destacar a intensa queda na taxa de intervenção em atos de concentração, o que reduz a restrição que o sistema de defesa da concorrência faz às estratégias empresariais e à reestruturação produtiva. Enquanto a notoriedade que resulta na disseminação das instituições de defesa da concorrência é necessariamente positiva, o mesmo não pode ser dito a respeito da redução da taxa de intervenção, ou seja, de uma jurisprudência mais permissiva. Nesse caso, o benefício de não constituir um obstáculo à reestruturação produtiva está associado a maior risco de aprovação de uma prática indesejável do ponto de vista do bem-estar social. No limite, a jurisprudência de tudo aprovar elimina qualquer benefício da defesa da concorrência, o que conduz à conclusão de que há um grau de permissividade ótimo, que atenue ambos os riscos e ainda exerça um efeito inibidor de práticas empresariais anticompetitivas. Os indicadores recentes do Cade, todavia, mostram maior preocupação em reduzir o risco de bloquear uma operação que deveria ter sido aprovada, o que pode sinalizar uma jurisprudência excessivamente permissiva.

O livro, sem dúvida, constitui importante fonte para pesquisadores e profissionais da área e referência obrigatória àqueles que participam ativamente do processo de reestruturação do sistema brasileiro de defesa da concorrência. Há, contudo, questões relevantes ao desenho institucional que, talvez por limitação de espaço, não são aprofundadas no livro. Entre elas, podem-se destacar a periodicidade de mandatos, a aplicação de decisão colegiada e as características de enforcement de decisões, sobretudo nos compromissos de desempenho. De qualquer modo, o livro trata dos problemas mais relevantes e polêmicos, em especial no momento em que o modelo de agência regulatória está sobre a mesa. $\bigcirc$

REFERÊNCIA BIBLIOGRÁFICA

REZENDE, F., PAULA, T. B. (Coord.). Infra-estrutura: perspectivas de reorganização regulação. Brasilia : Ipea, 1997. 